\title{
The effect of short-term dietary supplementation with glucose on gastric emptying in humans
}

\author{
BY KAREN M. CUNNINGHAM ${ }^{1}$, MICHAEL HOROWITZ ${ }^{2}$ AND \\ NICHOLAS W. REA D ${ }^{1, *}$ \\ ${ }^{1}$ Sub-Department of Human Gastrointestinal Physiology and Nutrition, K Floor, Royal Hallamshire \\ Hospital, Sheffield S10 $2 \mathrm{JF}$ \\ ${ }^{2}$ Department of Medicine, Royal Adelaide Hospital, North Terrace, Adelaide, SA 5000, Australia
}

(Received 11 October 1989 - Accepted 1 June 1990)

\begin{abstract}
In order to test whether gastric motility can adapt to changes in nutrient load, gastric emptying of hyperosmotic glucose and protein drinks was measured by applied potential tomography in two groups of ten volunteers following dietary supplementation with $400 \mathrm{~g}$ glucose/d for $3 \mathrm{~d}$. The half emptying time for the glucose test meal was significantly faster after the standard diet had been supplemented with glucose compared with the standard diet alone (median and range, 20.7 (4.6-36.8) v. 29.1 (19.8-38.4) min ; $P<0.05$ ), while the emptying of the protein drink (Oxo; Brooke Bond Ltd) was unchanged (median and range, 18.0 (12.5-23.6) v. 16.1 (9.6-22.7) min). These results suggest that rapid and specific adaptation of the small intestinal regulatory mechanisms for gastric emptying of nutrient solutions can occur in response to increases in dietary load. This adaptation may be explained by desensitization of nutrient receptors or by a reduction in the area of receptor field exposed to nutrients caused by increased absorption of glucose in the upper small intestine.
\end{abstract}

Gastric emptying: Glucoreceptors: Intestinal adaptation

Little is known of the possible adaptation of the motor activity of the stomach to changes in the nutrient content of the diet. Patients with anorexia nervosa or starvation have an abnormally slow delivery of nutrients from the stomach (Keys et al. 1950; Dubois et al. 1979; Holt et al. 1981; Franco et al. 1986; Rigaud et al. 1988; Robinson et al. 1988), while some investigators have reported an abnormally rapid gastric emptying in obese patients (Johansson \& Ekeland, 1976; Wright et al. 1981). These observations suggest the possibility that intestinal nutrient receptors controlling gastric emptying may be up-regulated or down-regulated in response to nutrient load.

The aim of the present experiment was to test this hypothesis by measuring the rate of gastric emptying of a hyperosmotic drink of glucose and a hyperosmotic drink containing protein in healthy male volunteers before and after a $3 \mathrm{~d}$ period during which the diet was supplemented with glucose.

\section{MATERIALS AND METHODS}

\section{Subjects}

Studies were carried out on twenty-six healthy male volunteers aged 19-29 years. None had taken any medication or suffered recent gastrointestinal upset before the studies. The weights of all subjects were within the normal range for their age and height and they all conformed to normal regular eating patterns. Each gave their written informed consent for the study to be performed. The protocols were approved (July 1987) by the Southern District Ethical Committee of the Sheffield Area Health Authority (Teaching). 


\section{Protocol}

Each study was divided into three $3 \mathrm{~d}$ periods. For the first $3 \mathrm{~d}$ volunteers ate a standard diet (Table 1), with $10.265 \mathrm{MJ}, 286.6 \mathrm{~g}$ carbohydrate, $95.5 \mathrm{~g}$ fat and $126.6 \mathrm{~g}$ protein (Paul \& Southgate, 1978), that included a total of $350 \mathrm{ml}$ low-carbohydrate orange squash ( $16.7 \mathrm{~kJ}$; Diabetic Whole Orange Drink; Boots, Nottingham) which was diluted $1: 3.5(\mathrm{v} / \mathrm{v})$ squash-water and consumed five times daily before each meal or snack, plus one drink taken by itself mid-afternoon. Volunteers then ate $a d$ lib. for a further $3 \mathrm{~d}$. Then on the final $3 \mathrm{~d}$, they ate the standard diet, supplemented with $400 \mathrm{~g}$ glucose (Boots), $80 \mathrm{~g}$ of which was added to each orange squash drink. This provided an additional daily intake of $6.276 \mathrm{MJ}$. Physical activity remained similar between dietary periods.

After each $3 \mathrm{~d}$ diet period, gastric emptying of a hyperosmotic drink of either glucose or a protein solution (Oxo; Brooke Bond Ltd, Croydon, Surrey) was measured in two groups of ten volunteers. As the order of the dietary periods was not randomized an additional six volunteers underwent two tests of gastric emptying of glucose separated by $7 \mathrm{~d}$. Care was taken to ensure that the subjects ingested a similar diet unsupplemented with glucose for the $3 \mathrm{~d}$ before each test.

All gastric-emptying tests commenced between 09.30 and 10.00 hours, following an overnight $12 \mathrm{~h}$ fast, during which no drinks were consumed.

Before each meal, subjects scored their desire to eat and the quantity of food they felt they could eat on visual analogue scales.

\section{Gastric emptying}

Gastric emptying was measured by the non-invasive technique of applied potential tomography (Avill et al. 1987; Mangnall et al. 1987), which measures the change in the resistivity or impedance of the stomach contents. This technique requires the administration of $800 \mathrm{mg}$ cimetidine (Tagamet; SK\&F, Philadelphia, PA., USA) approximately $1 \mathrm{~h}$ before the start of the gastric-emptying study to suppress acid secretion, which can also affect measurements of resistivity (Avill et al, 1987). The test meals were $68.2 \mathrm{~g}$ glucose $(1.070 \mathrm{MJ})$, made up to $350 \mathrm{ml}$ with distilled water $(1174 \mathrm{mOsmol} / 1)$, and $12 \mathrm{~g} \mathrm{Oxo}(115 \mathrm{~kJ}$, $4.6 \mathrm{~g}$ protein, $0.4 \mathrm{~g}$ fat, $1.4 \mathrm{~g}$ carbohydrate) dissolved in boiling water and made up to $350 \mathrm{ml}$ with distilled water $(370 \mathrm{mOsmol} / 1)$. Cumulative images of epigastric impedance were generated at intervals of $1 \mathrm{~min}$ and stored on computer. To analyse these, a region of interest was drawn around the stomach and the resistivity within this region was calculated and expressed as a percentage of the change in resistivity generated by ingesting the drink to yield a profile of gastric emptying. The studies were processed and analysed without knowledge of the phase of the study.

\section{Statistical analysis}

The statistical analysis of the difference in paired observations between the standard and high-carbohydrate diet was assessed by the Wilcoxon signed rank test. Values are shown as medians and ranges unless otherwise stated.

\section{RESULTS}

\section{Effects of dietary glucose supplements on gastric emptying}

The rate of gastric emptying of the glucose drink was significantly faster after supplementation of the standard diet for $3 \mathrm{~d}$ with $400 \mathrm{~g}$ glucose (Fig. 1) than after the standard diet alone (median and range, half emptying time $\left(t_{\frac{1}{2}} ; \min \right) 20 \cdot 7(4 \cdot 6-36 \cdot 8)$ v. $29 \cdot 1$ $(19 \cdot 8-38 \cdot 4) ; P<0.05)$. 
Table 1. Food ingested by the subjects during the study periods

* Breakfast (carbohydrate $86.35 \mathrm{~g}$, fat $13.9 \mathrm{~g}$, protein $17.6 \mathrm{~g}, 2.136 \mathrm{MJ}$ )

$50 \mathrm{~g}$ Cornflakes (St Martins)

$200 \mathrm{ml}$ semi-skimmed milk (homogenized, pasteurized)

Two medium slices bread (Homepride)

$10 \mathrm{~g}$ butter (Dairy Crest foods)

Cup of coffee with $50 \mathrm{ml}$ milk and no sugar

* Lunch (carbohydrate $103.8 \mathrm{~g}$, fat $36.9 \mathrm{~g}$, protein $49.5 \mathrm{~g}, 3.845 \mathrm{MJ}$ )

Four medium slices bread (Homepride)

$20 \mathrm{~g}$ butter

$100 \mathrm{~g}$ ham (cooked, lean)

$100 \mathrm{~g}$ tomatoes

Two chocolate biscuits (McVities)

One apple

Cup of coffee

* Mid-afternoon

* Tea (carbohydrate $70.3 \mathrm{~g}$, fat $35.7 \mathrm{~g}$, protein $55.6 \mathrm{~g}, 3.391 \mathrm{MJ}$ )

Beef stew and dumplings (Marks \& Spencer)

$100 \mathrm{~g}$ carrots (Presto)

$200 \mathrm{~g}$ cauliflower

Low-fat yoghurt (Marks \& Spencer)

Cup of coffee

* Supper (carbohydrate $26 \mathrm{~g}$, fat $9 \mathrm{~g}$, protein $3.9 \mathrm{~g}, 810 \mathrm{~kJ}$ )

Cup of coffee

Two chocolate biscuits (McVities)

* Consumption of $350 \mathrm{ml}$ diabetic orange squash $(16.7 \mathrm{~kJ})$ with or without $88 \mathrm{~g}$ glucose $(1.255 \mathrm{MJ})$. The addition of glucose gave an extra $400 \mathrm{~g}$ carbohydrate $(6 \cdot 276 \mathrm{MJ} / \mathrm{d})$.

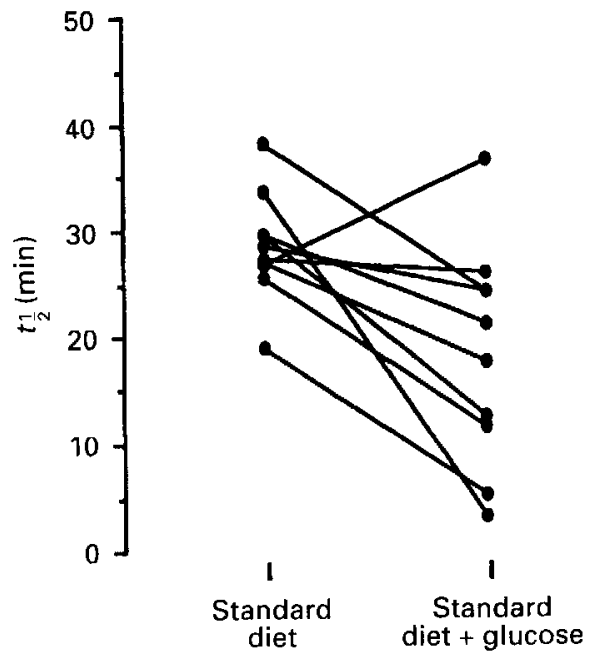

Fig. 1. The effect of dietary supplementation with $400 \mathrm{~g}$ glucose for $3 \mathrm{~d}$ on the half-time for gastric emptying $\left(t_{\mathrm{t}}\right)$ of a hyperosmotic glucose meal in ten healthy volunteers. $P<0.05$. For details of procedures, see p. 16 and Table 1 . 


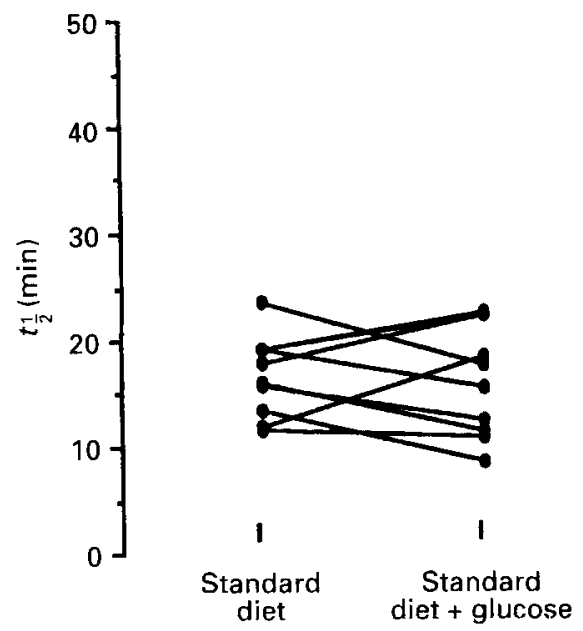

Fig. 2. The effect of dietary supplementation with $400 \mathrm{~g}$ glucose for $3 \mathrm{~d}$ on the half-time for gastric emptying ( $\left.t_{\frac{1}{1}}\right)$ of a hyperosmotic protein meal (Oxo, Brooke Bond Ltd) in ten healthy volunteers. For details of procedures, see p. 16 and Table 1.

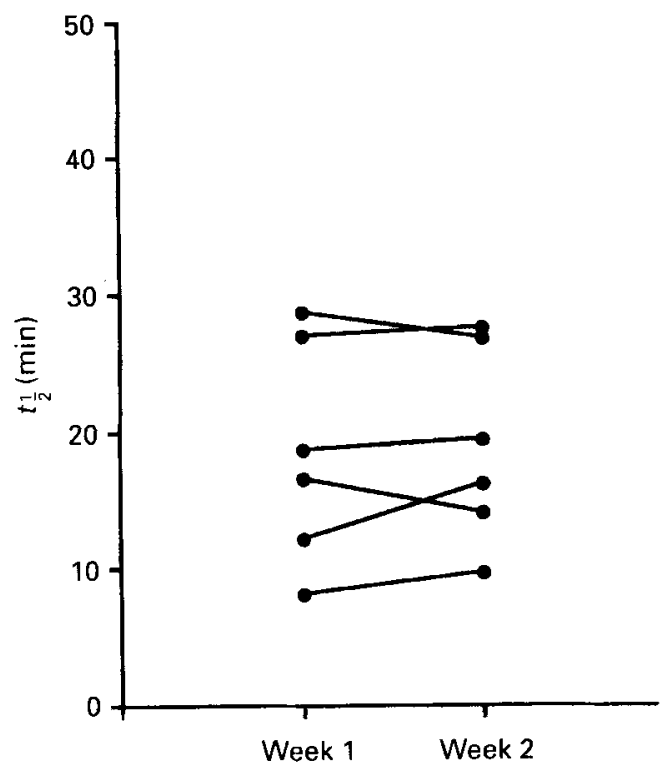

Fig. 3. Repeated measurements of the half-time for gastric emptying ( $\left.t_{\frac{1}{2}}\right)$ of a hyperosmotic glucose meal in six normal volunteers. For details of procedures, see p. 16 and Table. 1.

In contrast, the rate of gastric emptying of the Oxo test meal did not change following dietary supplementation with glucose (Fig. 2) $\left(t_{\frac{1}{2}}(\mathrm{~min}) 18 \cdot 0(12 \cdot 5-23 \cdot 6)\right.$ v. 16.1 (9.6-22.7)).

\section{Reproducibility of gastric emptying}

There was no significant difference in the $t_{\frac{1}{2}}(\mathrm{~min})$ for the emptying of glucose measured 1 week apart while subjects were ingesting a regular diet of their own choice (median and range, $18.4(8 \cdot 0-28 \cdot 8)$ v. $18.2(9 \cdot 6-26 \cdot 8)$ ) (Fig. 3). 


\section{DISCUSSION}

Our results show that supplementing the diet with drinks of glucose for $3 \mathrm{~d}$ accelerates the emptying of a hyperosmotic glucose drink from the stomach. This suggests that the mechanism that normally delays gastric emptying of glucose has undergone adaptive changes due to high exposure to glucose. In contrast, glucose supplementation did not alter the gastric emptying of the Oxo drink. This result suggests that the adaptation may be specific to glucose, although further studies with meals of different composition will be needed to establish this conclusion.

There are two possible mechanisms for this adaptive change. The first is a downregulation of glucose receptors, such that more glucose is required to elicit a maximum braking effect on gastric emptying. The second is a decrease in the area of small intestine exposed to glucose. Lin et al. (1989) have recently shown, by experiments using re-entrant cannulas in the dog, that the degree to which glucose solutions inhibit gastric emptying depends on the length of small intestine exposed to the solutions. Since the upper intestine adapts to increased exposure to glucose by increasing glucose uptake (Weser, 1981), less glucose will reach the lower small intestine and the number of glucose receptor sites recruited will be reduced resulting in a diminished braking effect on gastric emptying.

In conclusion, the present study shows that energy delivery from the stomach to the small intestine can be increased by exposure to specific nutrients and illustrates how the previous dietary history can influence the gastric emptying of nutrient solutions; a point to consider when interpreting gastric emptying values from different groups of subjects.

\section{REFERENCES}

Avill, R., Magnall, Y. F., Bird, N. C., Brown, B. H., Barber, D. C., Seagar, A. D., Johnson, A. G. \& Read, N.W. (1987). Applied potential tomography. A new non-invasive technique for measuring gastric emptying. Gastroenterology 92, 1019-1026.

Dubois, A., Gross, H. A., Ebert, M. H.\& Castell, D. O. (1979). Altered gastric emptying and secretion in primary anorexia nervosa. Gastroenterology $77,319-323$.

Franco, V. H. M., Collares, E. F. \& Troncon, L. E. A. (1986). Gastric emptying in children. IV. Studies on kwashiorkor and marasmic kwashiorkor. Archives of Gastroenterology of São Paulo 23, 42-46.

Holt, S., Ford, M. J., Grant, S. \& Heading, R. C. (1981). Abnormal gastric emptying in primary anorexia nervosa. British Journal of Psychiatry 139, 550-552.

Johansson, C. \& Ekeland, K. (1976). Relation between body weight and the gastric and intestinal handling of an oral caloric load. Gut 17, 456-462.

Keys, A., Brozek, J. \& Henscel, A. (1950). The Biology of Human Starvation, pp. 587-600. Minneapolis : University of Minnesota Press.

Lin, H. C., Doty, J. E., Reedy, T. J. \& Meyer, J. M. (1989). Inhibition of gastric emptying by glucose depends on length of intestine exposed to nutrient. American Journal of Physiology 256, G404-G411.

Mangnall, Y. F., Baxter, A. J., Avill, R., Bird, N. C., Brown, B. H., Barber, D. C., Seagar, A. D., Johnson, A. G. \& Read, N. W. (1987). Applied potential tomography: a new non-invasive technique for assessing gastric function. Clinical Physics and Physiological Measurement 8 (A), 119-129.

Paul, A. A. \& Southgate, D. A. T. (1978). McCance and Widdowson's The composition of Foods. Fourth revised and extended edition of MRC Special Report no. 297. London: H.M. Stationery Office.

Rigaud, D., Bedig, G., Marrouche, M., Vulpillat, M., Bonfils, S. \& Apelbaum, M. (1988). Delayed gastric emptying in anorexia nervosa is improved by completion of a renutrition program. Digestive Diseases and Sciences 33, 919-925.

Robinson, P. H., Clarke, M. \& Barrett, J. (1988). Determinants of delayed gastric emptying in anorexia nervosa and bulimia nervosa. Gut 29, 458-464.

Weser, E., Tawil, T. \& Fletcher, J. T. (1981). Stimulation of small bowel mucosal growth by gastric infusion of different sugars in rats maintained on total parental nutrition. In Mechanisms of Intestinal Adaptation, pp. 175-185. [J. W. L. Robinson, R. H. Dowling, and E. O. Reiken, editors]. Lancaster: MTP Press.

Wright, R. A., Kim, Y. C. \& Fleeman, C. (1981). Solid and liquid gastric emptying in obese patients. Gastroenterology 80, 1320. 